\title{
Molecular phylogeny of the arthrostylidioid bamboos (Poaceae: Bambusoideae: Bambuseae: Arthrostylidiinae) and new genus Didymogonyx
}

\author{
Christopher D. Tyrrell ${ }^{\mathrm{a}, *}$, Ana Paula Santos-Gonçalves ${ }^{\mathrm{b}}$, Ximena Londoño ${ }^{\mathrm{c}}$, Lynn G. Clark ${ }^{\mathrm{a}}$ \\ ${ }^{a}$ Dept. of Ecology, Evolution and Organismal Biology, Iowa State University, 251 Bessey Hall, Ames, IA 50011, USA \\ ${ }^{\mathrm{b}}$ Universidade Federal de Viçosa, Departamento de Biologia Vegetal, CCB2, Viçosa, 36570-000 Minas Gerais, Brazil \\ ' Instituto Vallecaucano de Investigaciones Cientificas (INCIVA), AA 11574, Cali, Colombia
}

\section{A R T I C L E I N F O}

Article history:

Received 17 January 2012

Revised 18 May 2012

Accepted 29 May 2012

Available online 6 June 2012

\section{Keywords:}

Arthrostylidiinae

Woody bamboo

Chloroplast markers

Didymogonyx

Guaduinae

Phylogeny

\begin{abstract}
A B S T R A C T
We present the first multi-locus chloroplast phylogeny of Arthrostylidiinae, a subtribe of neotropical woody bamboos. The morphological diversity of Arthrostylidiinae makes its taxonomy difficult and prior molecular analyses of bamboos have lacked breadth of sampling within the subtribe, leaving internal relationships uncertain. We sampled 51 taxa, chosen to span the range of taxonomic diversity and morphology, and analyzed a combined chloroplast DNA dataset with six chloroplast regions: ndhF, trnD-trnT, trnC-rpoB, rps16-trnQ, trnT-trnL, and rpl16. A consensus of maximum parsimony and Bayesian inference analyses reveals monophyly of the Arthrostylidiinae and four moderately supported lineages within it. Six previously recognized genera were monophyletic, three polyphyletic, and two monotypic; Rhipidocladum sect. Didymogonyx is here raised to generic status. When mapped onto our topology, many of the morphological characters show homoplasy.
\end{abstract}

(c) 2012 Elsevier Inc. All rights reserved.

\section{Introduction}

The bamboos, with about 1450 species, are the only grass subfamily (Poaceae: Bambusoideae) to diversify primarily in forests (BPG, 2006a, 2012; Bouchenak-Khelladi et al., 2010; GPWG, 2001). Our understanding of Bambusoideae taxonomy is in a state of flux, but the emerging picture based on molecular sequence data (Sungkaew et al., 2009) is that the bamboos evolved into three main lineages: woody, mainly north temperate species (Arundinarieae), woody tropical species (Bambuseae), and herbaceous bamboos (Olyreae). The Bambuseae, including nearly 800 described species, is usually classified into seven subtribes, of which four are paleotropical and three are neotropical (BPG, 2012; Judziewicz et al., 1999; Soderstrom and Ellis, 1987). The present work is focused on one morphologically diverse but understudied subtribe of neotropical woody bamboos.

The three neotropical subtribes of Bambuseae are Arthrostylidiinae (172 described species), Chusqueinae (160 described species) and Guaduinae (45 described species) (BPG, 2012; Fisher et al., 2009; Judziewicz et al., 1999). The Arthrostylidiinae plus Guaduinae are recovered as a moderately- to well-supported clade

\footnotetext{
* Corresponding author. Present address: Biology Dept., University of New Brunswick, P.O. Box 4400, Fredericton NB, Canada E3B 5A3. Fax: +1 5064526271.

E-mail addresses: christopher.d.tyrrell@unb.ca (C.D. Tyrrell), santosgonc@gmail. com (A.P. Santos-Gonçalves), ximelondo@gmail.com (X. Londoño), lgclark@iastate. edu (L.G. Clark).
}

(BPG, in preparation; Clark et al., 2007; Sungkaew et al., 2009; Zhang and Clark, 2000). In recent studies, this clade is moderately supported as sister to Chusqueinae, thus forming a neotropical woody bamboo clade, which is sister to the paleotropical woody bamboo clade (BPG, in preparation; Sungkaew et al., 2009).

The results of the BPG (in preparation), Sungkaew et al. (2009) and Zhang and Clark (2000) support the monophyly of each subtribe; however, each is represented by only one to three exemplar taxa. Other molecular analyses included more species but discovered reciprocally misplaced taxa. Guala et al. (2000) generated a phylogeny that included seven Arthrostylidiinae and two Guaduinae species, and found that two presumed Guaduinae taxa were allied with Arthrostylidiinae. Conversely, Ruiz-Sanchez et al. (2008, 2011) found two species of Arthrostylidiinae that resolved within the Guaduinae based on plastid sequence data. Guala et al. (2000) recovered a topology with moderate support for the two subtribes as sister clades, whereas Ruiz-Sanchez et al. (2011) recovered a robustly supported Guaduinae sister to the Arthrostylidiinae, but without support. Clark et al. (2007) and Ruiz-Sanchez et al. (2008), however, recovered a robustly monophyletic Guaduinae derived from within a paraphyletic Arthrostylidiinae.

The Arthrostylidiinae can be distinguished from other woody bamboo subtribes using branch leaf micromorphology and anatomy (Soderstrom and Ellis, 1987). The leaf blades of Arthrostylidiinae possess a unique combination of intercostal sclerenchyma fibers in the blades and simple vasculature in the midrib, and the leaf blades are basically hypostomatic with papillae usually 
developed only on the abaxial epidermis. A green marginal stripe on the abaxial leaf epidermis (due to reduced or no wax deposition) is also characteristic of Arthrostylidiinae, although this is seen occasionally in other neotropical Bambuseae, Olyreae, and even some Arundinarieae (BPG, 2012; Judziewicz et al., 1999; Soderstrom and Ellis, 1987; pers. obs. by all authors). In several taxa of Arthrostylidiinae, stomates have been observed on the adaxial surface over the abaxial green stripe, but they appear to be restricted to this region and it is unknown how general this pattern is (Santos-Gonçalves, 2005). Arthrostylidiinae also have sympodial rhizomes, usually a single primary branch bud at each node, rudimentary florets terminating the spikelets or pseudospikelets, and reflexed pseudopetioles (except in Glaziophyton Franch., Filgueirasia Guala and some species of Aulonemia Goudot; BPG, 2012).

With 172 described species currently classified into 13 genera exhibiting a broad range of life forms, Arthrostylidiinae is arguably the most morphologically diverse subtribe of neotropical woody bamboo. In comparison, the Chusqueinae include nearly the same number of described species but only one genus, Chusquea Kunth, is recognized based on a uniform spikelet structure and papillate subsidiary cells (Fisher et al., 2009). The characters most commonly used to distinguish among genera of Arthrostylidiinae, however, often intergrade in a "mosaic pattern of variation" (Clark and Londoño, 1991) making taxonomy and phylogenetic inference difficult (Judziewicz et al., 1999). McClure (1973) notes that "such divergent attributes are connected by intermediate expressions to form clines, both from one species to another and (in some cases) within the same specimen." Notable morphological enigmas within the subtribe include internode length pattern, culm leaf blade orientation, vegetative bud prophyll shape, branching architecture, synflorescence form, the occurrence of pseudospikelets, and fruit anatomy. The observations summarized in the following paragraphs are based on decades of field work in the Neotropics and examination of thousands of herbarium specimens by Santos-Gonçalves, Londoño and Clark as well as on information from the literature, primarily the BPG (2012), Judziewicz et al. (1999), and McClure (1973).

Patterns of unequal culm internode lengths (length dimorphism) are a feature observed in species of five Arthrostylidiinae genera: Arthrostylidium Rupr., Glaziophyton, Myriocladus Swallen, Aulonemia, and Rhipidocladum McClure. The patterns vary in expression, but are sometimes species specific and thus diagnostic. Arthrostylidium schomburgkii Munro and Glaziophyton usually have one long basal internode (as much as $5 \mathrm{~m}$ long in the former) followed successively by much shorter internodes. A similar pattern is seen in Myriocladus which has one or two basal elongated internodes, and several short internodes near the culm apex or one elongated internode regularly alternating with a few shorter ones. Internodes of Aulonemia queko, Au. herzogiana (Henrard) McClure, and $A u$. hirtula alternate one to four short with one long (up to $2 \mathrm{~m}$ in length). The two species of Rhipidocladum sect. Didymogonyx demonstrate a regular alternation of one short and one long internode along the entire length of their culms (Clark and Londoño, 1991). The remaining species display uniformly subequal internode lengths.

All members of Rhipidocladum, Filgueirasia, Alvimia C.E. Calderón ex Soderstr. \& Londoño, and Glaziophyton (monotypic), several species of Arthrostylidium, Aulonemia ulei, and two species of Atractantha McClure have erect culm leaf blades which are confluent with the sheath. The remaining species of the subtribe have culm leaf blades that are reflexed and constricted into a pseudopetiole where the blade meets the sheath. Reflexed culm leaf blades are generally deciduous, while erect blades tend to be persistent.

With the exception of the two species of Filgueirasia, all species in the subtribe have a single bud per node, each covered by a protective, two-keeled prophyll. In $R$. sect. Didymogonyx and
Myriocladus the prophylls are cordate in shape. The remaining taxa have triangular shaped prophylls.

Arthrostylidioid bamboos typically have branch complements with one dominant branch that arises from the main culm often with several smaller branches arising laterally, a pattern commonly seen in other woody bamboos (e.g., Bambusa Schreb.). Yet the branch complements of several genera deviate from this arrangement. Atractantha and Athroostachys Benth. exhibit three to five subequal branches, which may or may not rebranch, arising from each node; Aulonemia ulei has five to seven subequal branches per node. Actinocladum McClure ex Soderstr., Merostachys Spreng., and Rhipidocladum share an unusual branching morphology superficially resembling a hand fan. This is termed apsidate branching (McClure, 1973), referring to the numerous subequal secondary branches that radiate in an apsidal or vault-like fashion from a flattened triangular surface (postulated to be a modification of the dominant branch); we here use the less technical term "fan-branching" to describe this morphology. In Arthrostylidium, Alvimia, Atractantha, Aulonemia, Colanthelia and Elytrostachys McClure, the branches arise from a raised, ellipsoidal base, called a promontory, which either continues as a dominant branch (often producing small lateral branches from its basal nodes) or separates into multiple subequal branches. If the latter, the branches are not orderly as in fan-branching. Arthrostylidium merostachyoides manifests a combination of promontory and fan-branching morphologies when mature.

The most common synflorescence forms in Arthrostylidiinae are paniculate or racemose with a straight axis, but this character exemplifies the mosaic variation seen in the subtribe. Arthrostylidium venezuelae, Ar. sarmentosum Pilg., Ar. multispicatum, Ar. ecuadorense Judz. \& L.G. Clark, Ar. virolinensis Londoño \& L.G. Clark, and $R$. harmonicum all have racemose synflorescences with a geniculate or zig-zag axis. This kinked morphology is the result of swollen pulvini at the base of the spikelets. Two other species, Athroostachys capitata Benth. and Atractantha radiata, have synflorescences that are contracted into prickly, globose clusters. The spikelets of most arthrostylidioid species arise bilaterally along the synflorescence axis. Those of Merostachys, however, are secund, inserted on one side only. This is also characteristic of Arthrostylidium merostachyoides and Rhipidocladum maxonii, and many other species of Rhipidocladum have nearly secund synflorescences.

Most arthrostylidioid species also have conventional spikelets, but pseudospikelets occur in three genera. Pseudospikelets differ from spikelets in that the former rebranch into other spikelet-like units from bud-bearing bracts within what appears to be a spikelet. Additionally, taxa with pseudospikelets also have subtending bracts and prophylls at the base of each branch. Pseudospikelets are observed in Elytrostachys, Alvimia, and Atractantha (except for At. amazonica Judz. \& L.G. Clark). Glaziophyton, while lacking budbearing bracts, has the subtending bracts and prophylls typically found in taxa with pseudospikelets.

Most arthrostylidioid genera have a typical grass fruit, the grain-like basic caryopsis, characterized by a pericarp that is fully adnate to the seed coat (Sendulsky et al., 1987). Actinocladum and Merostachys both possess a fruit in which the pericarp is separable from the seed coat, known as a nucoid or nut-like caryopsis. Furthermore, the caryopsis of Alvimia is bacoid, having an enlarged, fleshy pericarp superficially resembling a berry (Soderstrom and Londoño, 1988).

Prior molecular analyses were not specifically focused on the Arthrostylidiinae and, given the morphological variation across the subtribe, lacked breadth of sampling. Thus, the monophyly of the subtribe has not been adequately tested and internal relationships remain ambiguous. Our objectives are to (1) generate a phylogenetic hypothesis for Arthrostylidiinae using multi-locus plastid sequence data and the broadest possible sampling of its 
taxonomic and morphological diversity; (2) test the monophyly of the subtribe and all genera for which multiple taxa could be sampled; and (3) examine the evolution of the apparently mosaic morphological characters that have been used to distinguish among genera in this subtribe using our phylogenetic hypothesis. We conclude with a discussion of the implications of our findings for generic circumscription and recommendations for future work in the subtribe.

\section{Methods and materials}

\subsection{Taxon sampling}

A total of 51 species, chosen to span a range of genera and morphologies, were analyzed (Table 1). Forty-five taxa represent 11 of the 13 recognized genera of Arthrostylidiinae and five taxa represent the five genera currently recognized in the Guaduinae. Bambusa vulgaris (paleotropical woody clade) is the designated outgroup based on Clark et al. (2007) and Ruiz-Sanchez et al. (2008). Leaf material was either collected in the field and silicagel dried (Chase and Hills, 1991), obtained fresh from greenhouse specimens, or removed with permission from herbarium specimens.

\subsection{DNA extraction, sequencing, alignment, and character coding}

Total genomic DNA was extracted following CTAB-isopropanol precipitation protocols (Paterson et al., 1993) or using DNeasy ${ }^{\circledR}$ Plant Mini kits (July 2006 version; QIAGEN, Valencia, California, USA) with a modified protocol (Triplett and Clark, 2010). Six chloroplast DNA regions: one gene (ndhF $3^{\prime}$ half), four intergenic spacers (trnD-trnT, trnC-rpoB, rps16-trnQ, trnT-trnL), and an intron (rpl16), were amplified by polymerase chain reaction (PCR) on an MJ Research PTC-200 thermal cycler (Bio-Rad Laboratories, Inc., Hercules, CA USA) in $40 \mu \mathrm{L}$ quantities. Amplification primers, internal sequencing primers, and thermal cycler protocols for ndhF, trnD-trnT, trnC-rpoB, rps16-trnQ, and trnT-trnL follow Triplett and Clark (2010). Amplification primers for rpl16 were F71 and R1661 of Jordan et al. (1996), internal sequencing primers were R1516 (Kelchner and Clark, 1997) and an unpublished primer, CCA TCC CAC CCA ATG AAG, developed by Kelchner. Thermal cycler protocol for rpl16 began with initialization at $95{ }^{\circ} \mathrm{C}$ for $2 \mathrm{~m}$, then 35 cycles of $95^{\circ} \mathrm{C}$ for $1 \mathrm{~m}$ denaturation, $50{ }^{\circ} \mathrm{C}$ for $10 \mathrm{~s}$ annealing, followed by a $50 \mathrm{~s}$ temperature ramp increasing $0.3^{\circ} \mathrm{C} / \mathrm{s}$ until elongation at $65^{\circ} \mathrm{C}$ for $4 \mathrm{~m}$. Final elongation was carried out at $65^{\circ} \mathrm{C}$ for $5 \mathrm{~m}$ and products were then held at $4{ }^{\circ} \mathrm{C}$. Amplification products were cleaned with Antarctic phosphatase (5 units, New England Biolabs, Ipswich, MA, USA) and exonuclease I (10 units, New England Biolabs) followed by ethanol precipitation. Asymmetric sequencing reactions were carried out using BigDye ${ }^{\mathrm{TM}}$ Terminators v3.1 (Applied Biosystems Inc., Foster City, CA USA) on a Perkin-Elmer Applied Biosystems GeneAmp PCR System 9600 thermal cycler, and cleaned using a Sephadex plate (Edge BioSystems, Gaithersburg, MD USA). Sequences were read on an automated $3730 \times 1$ DNA Analyzer (Applied Biosystems) at the DNA Facility of the Iowa State University Office of Biotechnology.

Sequence electropherograms were verified and base-called using 4Peaks (Griekspoor and Groothuis, 2006). Contigs were manually assembled and aligned in Se-Al version 2.0a11 (Rambaut, 2002) using Oryza sativa L. (GenBank ID: NC001320) as a reference. Primer regions were trimmed from the final sequence. Biologically significant alignments were attempted using a parsimony concept (Morrison, 2006). Patterns for known molecular evolutionary events such as slip-strand mispairing, stem-loop secondary structures, and minute hairpins, were sought and aligned as recommended in Kelchner (2000) and Kelchner and Wendel (1996). Gaps of identical size and position were binary coded relative to the outgroup (Giribet and Wheeler, 1999) and appended to the DNA sequence matrix. Autapomorphic and parsimony-uninformative indels were not scored, and were excluded along with other gaps prior to analysis. Individual sequences are available in GenBank (Table 1).

\subsection{Phylogenetic analysis}

Separate analyses of the data, partitioned by locus, revealed little incongruence between phylogenetic topologies. Therefore, we assumed all loci track the same evolutionary history and combined regions into one dataset for use in analyses.

Unweighted maximum parsimony (MP) analysis on the data with binary coded gaps and indels was carried out in PAUP* (Swofford 2002) using full heuristic search with 1000 random addition sequences, tree bisection and reconnection (TBR) swapping, and no topological constraints. Bootstrap support (BS) values (Felsenstein, 1985) for MP analyses were estimated from 10,000 replicates with the above heuristic settings. Bremer (1994) decay index (DI) values were calculated using TreeRot version 3 (Sorenson and Franzosa, 2007) with PAUP*.

The GTR $+\Gamma+$ I model of evolution was selected by the AIC criterion and hierarchical likelihood ratio test for each region and the combined matrix using MrModeltest version 2.3 (Nylander, 2004). Since the selected models were the same, the combined data were analyzed. Bayesian inference (BI) was performed in MrBayes version 3.1.2 (Ronquist and Huelsenbeck, 2003). BI was carried out using the chloroplast nucleotide data only, gap and indel coding was only used in parsimony analysis. Markov Chain Monte Carlo (MCMC) was implemented with eight chains in four runs over $5,000,000$ generations, sampled every 1000 th generation. We assessed the quality of the MCMC simulations by ensuring the average standard deviation of split frequencies was consistently below 0.01 and examining posterior probabilities of splits with AWTY (Wilgenbusch et al., 2004). We discarded the initial 10\% of sampled generations as burn-in and used MrBayes to generate a majority rule consensus tree with posterior probabilities (PPs) for each recovered clade.

A consensus phylogeny of the shortest trees from ten parsimony ratchet searches was also constructed using PRAP (Müller, 2004) with $25 \%$ of the characters upweighted over 200 iterations. This topology agreed with the recovered trees from both the Bayesian and unratcheted parsimony analyses.

Given that branch support tends to be overestimated by Bayesian PP and underestimated by bootstrap values (Simmons et al., 2004), we adopted a conservative interpretation of clade support using the following criteria: well supported $=90-100 \%$ BS, 0.99 $1.00 \mathrm{PP}$, and $>5 \mathrm{DI}$; moderately supported $=80-89 \% \mathrm{BS}, 0.95-0.98$ $\mathrm{PP}$, and 3-5 DI; poorly supported $=<79 \% \mathrm{BS},<0.95 \mathrm{PP}$ and $<3 \mathrm{DI}$.

Several constrained topologies were constructed and used to test whether the combined data provided sufficient evidence to reject particular topological hypotheses of various taxa and morphological characters (e.g., monophyly of Arthrostylidiinae, Arthrostylidium, Rhipidocladum, Aulonemia, or a single origin of fan-branching, etc.). Two-tailed Kishino-Hasegawa $(\mathrm{KH})$ and Templeton non-parametric tests were performed on parsimony scores as implemented in PAUP* (Table 2).

\subsection{Morphological character mapping}

We coded a matrix of morphological character states for each taxon based on the voucher and conspecific herbarium specimens and observations recorded in the literature as cited in the introduction (Table 3). Because this is an initial assessment, we focused 
Table 1

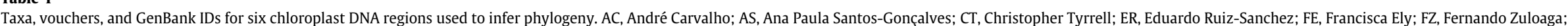

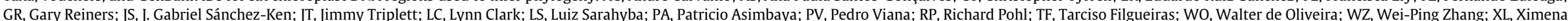
Londoño. Taxa that failed to amplify for a region are indicated by a dash.

\begin{tabular}{|c|c|c|c|c|c|c|c|c|}
\hline \multirow[t]{2}{*}{ Taxon } & \multirow[t]{2}{*}{ Voucher } & \multirow[t]{2}{*}{ Origin } & \multicolumn{6}{|c|}{ GenBank ID } \\
\hline & & & $\mathrm{ndhF}$ & rpL16 Intr. & $\operatorname{trnC}-\mathrm{rpoB}$ & $\operatorname{trnD}$-trnT & rps16-trnQ & $\operatorname{trnT}$-trnL \\
\hline \multicolumn{9}{|l|}{ Bambuseae Kunth ex Dumort. } \\
\hline \multicolumn{9}{|l|}{ Arthrostylidiinae Soderstr. \& R.P.Ellis } \\
\hline Actinocladum verticillatum (Nees) McClure ex Soderstr. & TF s.n. & Brazil & JQ408524 & JQ408570 & JQ408485 & JQ408623 & JQ408445 & JQ408586 \\
\hline Alvimia auriculata Soderstr. \& Londoño & AS 598 & Brazil & JQ408525 & - & JQ408486 & JQ408624 & JQ408446 & JQ408587 \\
\hline Alvimia gracilis Soderstr. \& Londoño & AC 4389 & Brazil & JQ408526 & JQ408571 & JQ408487 & JQ408625 & JQ408447 & JQ408588 \\
\hline Arthrostylidium cubense Rupr. & XL 957 & Cuba & JQ408529 & JQ408572 & - & JQ408628 & JQ408450 & JQ408590 \\
\hline Arthrostylidium merostachyoides R.W.Pohl & CT et al. 36 & Costa Rica & JQ408531 & - & JQ408491 & - & JQ408452 & - \\
\hline Arthrostylidium multispicatum Pilg. & LC \& GR 1508 & Puerto Rico & JQ408532 & JQ408574 & - & JQ408630 & JQ408453 & JQ408592 \\
\hline Arthrostylidium pubescens Rupr. & CT et al. 42 & Costa Rica & JQ408533 & JQ408575 & - & JQ408631 & JQ408454 & - \\
\hline Arthrostylidium urbanii Pilg. & XL 851 & Cuba & JQ408534 & JQ408576 & JQ408492 & JQ408632 & JQ408455 & JQ408594 \\
\hline Arthrostylidium venezuelae (Steud.) McClure & CT et al. 43 & Costa Rica & JQ408535 & - & JQ408493 & JQ408633 & - & - \\
\hline Arthrostylidium sp. & LC et al. 1101 & Ecuador & JQ408530 & JQ408573 & JQ408490 & JQ408629 & JQ408451 & JQ408591 \\
\hline Arthrostylidium sp. & XL 900 & Colombia & JQ408528 & - & JQ408489 & JQ408627 & JQ408449 & JQ408593 \\
\hline Atractantha aureolanata Judz. & AS 596 & Brazil & JQ408536 & - & JQ408494 & JQ408634 & - & JQ408595 \\
\hline Atractantha cardinalis Judz. & AS 591 & Brazil & JQ408537 & - & JQ408495 & JQ408635 & JQ408456 & JQ408596 \\
\hline Atractantha radiata McClure & AC 4362 & Brazil & JQ408538 & JQ408577 & JQ408496 & JQ408636 & JQ408457 & JQ408597 \\
\hline Aulonemia amplissima (Nees) McClure & AS 492 & Brazil & JQ408539 & - & JQ408497 & JQ408637 & - & JQ408598 \\
\hline Aulonemia hirtula (Pilg.) McClure & LC \& PA 1412 & Ecuador & JQ408540 & - & JQ408498 & JQ408638 & - & - \\
\hline Aulonemia patriae R.W.Pohl & CT et al. 44 & Costa Rica & JQ408541 & - & JQ408499 & JQ408639 & JQ408458 & - \\
\hline Aulonemia patula (Pilg.) McClure & LC et al. 1075 & Ecuador & JQ408542 & JQ408578 & JQ408500 & JQ408640 & JQ408459 & JQ408599 \\
\hline Aulonemia queko Goudot & LC \& PA 1445 & Ecuador & JQ408543 & JQ408579 & JQ408501 & JQ408641 & JQ408460 & JQ408600 \\
\hline Aulonemia ulei (Hack.) McClure \& L.B.Sm. & LC \& XL 1048 & Brazil & JQ408544 & - & JQ408502 & JQ408642 & JQ408461 & JQ408601 \\
\hline Colanthelia cingulata (McClure \& L.B.Sm.) McClure & TF s.n. & Brazil & JQ408545 & - & - & JQ408643 & - & JQ408602 \\
\hline Colanthelia distans (Trin.) McClure & PV s.n. & Brazil & JQ408546 & - & JQ408503 & JQ408644 & - & JQ408603 \\
\hline Colanthelia intermedia (McClure \& L.B.Sm.) McClure & AS 553 & Brazil & - & - & - & JQ408645 & JQ408462 & JQ408604 \\
\hline Elytrostachys clavigera McClure & RP 13572 & Costa Rica & JQ408547 & - & - & - & - & - \\
\hline Elytrostachys typica McClure & XL 985 & Colombia & JQ408548 & - & - & JQ408646 & JQ408463 & - \\
\hline Filgueirasia arenicola (McClure) Guala & TF s.n. & Brazil & JQ408550 & - & JQ408505 & JQ408648 & JQ408465 & JQ408605 \\
\hline Filgueirasia cannavieira (Silveira) Guala & TF s.n. & Brazil & JQ408551 & JQ408580 & JQ408506 & JQ408649 & JQ408466 & JQ408606 \\
\hline Glaziophyton mirabile Franch. & LS et al. 1066 & Brazil & JQ408552 & U54748 & JQ408507 & JQ408650 & JQ408467 & JQ408607 \\
\hline Merostachys ternata Nees & LC \& WO 1023 & Brazil & JQ408555 & - & JQ408510 & JQ408653 & JQ408471 & JQ408610 \\
\hline Merostachys sp. & AC 4366 & Brazil & JQ408553 & - & JQ408508 & JQ408651 & JQ408469 & JQ408608 \\
\hline Merostachys sp. & AC 4378 & Brazil & JQ408554 & - & JQ408509 & JQ408652 & JQ408470 & JQ408609 \\
\hline \multicolumn{9}{|l|}{ Rhipidocladum sect. Rhipidocladum } \\
\hline Rhipidocladum harmonicum (Parodi) McClure & LC et al. 1128 & Ecuador & JQ408563 & JQ408582 & JQ408517 & JQ408661 & JQ408478 & JQ408615 \\
\hline Rhipidocladum sp. & LC 1464 & Ecuador & JQ408561 & JQ408581 & JQ408516 & JQ408659 & JQ408476 & JQ408622 \\
\hline \multicolumn{9}{|l|}{ Rhipidocladum sect. Didymogonyx L.G.Clark \& Londoño } \\
\hline Rhipidocladum geminatum (McClure) McClure & FE 2 & Venezuela & JQ408562 & - & - & JQ408660 & JQ408477 & JQ408614 \\
\hline Rhipidocladum aff. longispiculatum Londoño \& L.G.Clark & XL \& ER 995 & Colombia & JQ408558 & - & JQ408513 & JQ408656 & JQ408473 & - \\
\hline \multicolumn{9}{|l|}{ Rhipidocladum sect. Racemiflorum L.G.Clark \& Londoño } \\
\hline Rhipidocladum bartlettii (McClure) McClure & LC 1168 & Mexico & JQ408559 & - & JQ408514 & JQ408657 & JQ408474 & JQ408613 \\
\hline Rhipidocladum clarkiae R.W.Pohl & CT et al. 47 & Costa Rica & JQ408560 & - & JQ408515 & JQ408658 & JQ408475 & - \\
\hline Rhipidocladum maxonii (Hitchc.) McClure & CT et al. 46 & Costa Rica & JQ408564 & - & JQ408518 & JQ408662 & - & - \\
\hline Rhipidocladum neumannii Sulekic, Rúgolo \& L.G.Clark & LC \& FZ 1019 & Argentina & JQ408565 & JQ408583 & JQ408519 & JQ408663 & JQ408479 & JQ408616 \\
\hline Rhipidocladum pacuarense R.W.Pohl & CT et al. 41 & Costa Rica & JQ408566 & - & JQ408520 & JQ408664 & JQ408480 & - \\
\hline Rhipidocladum parviflorum (Trin.) McClure & TF s.n. & Brazil & JQ408567 & - & JQ408521 & JQ408665 & JQ408481 & JQ408617 \\
\hline Rhipidocladum pittieri (Hack.) McClure & LC \& WZ 1349 & Costa Rica & JQ408568 & JQ408584 & JQ408522 & JQ408666 & JQ408482 & JQ408618 \\
\hline Rhipidocladum racemiflorum (Steud.) McClure & CT \& JT 26 & Costa Rica & JQ408569 & JQ408585 & JQ408523 & JQ408667 & JQ408483 & JQ408619 \\
\hline Rhipidocladum sibilans Davidse, Judz. \& L.G.Clark & LC et al. 1524 & Venezuela & - & - & - & JQ408668 & JQ408484 & JQ408620 \\
\hline $\begin{array}{l}\text { Rhipidocladum sp. }\end{array}$ & TF s.n. & Brazil & JQ408557 & - & JQ408512 & JQ408655 & JQ408472 & JQ408621 \\
\hline
\end{tabular}




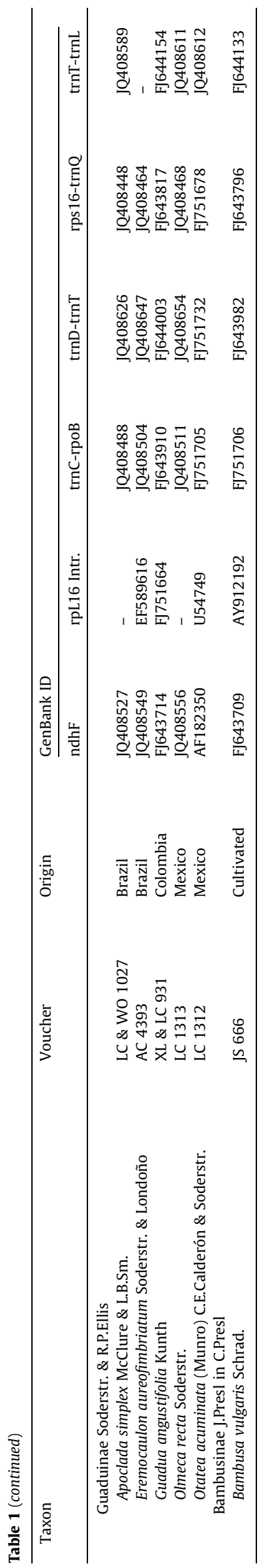

only on characters traditionally used to distinguish genera in this subtribe. Characters and coded states are listed in the legend on Fig. 2. Only taxa with subtending bracts, prophylls and bud-bearing bracts were scored as having pseudospikelets. The states were parsimony optimized on the combined consensus tree using MacClade (Maddison and Maddison, 2005). Alternative reconstructions resolved by accelerated and delayed transformation (ACCTRAN/DELTRAN) were explored. Fig. 2 graphically depicts state changes under delayed reconstruction. We also inferred ancestral states by likelihood reconstruction using the Markov k-state 1 parameter model (Mk1) in Mesquite (Maddison and Maddison, 2011); these results are available as electronic Supplementary Material.

\section{Results}

\subsection{Data matrix}

The combined, aligned data matrix was 6969 bp long, with 37 binary characters. Only 265 characters (3.8\%) were parsimony informative (PIC). Alignments for all regions averaged $1.15 \mathrm{~kb}$ in length: ndhF, 1163 bp (68 PIC); rpl16, 1055 bp (23 PIC); rps16trnQ 1217 bp (52 PIC); trnC-rpoB, 1343 bp (43 PIC); trnD-trnT, 1292 bp (37 PIC); and trnT-trnL, 862 (31 PIC). Regions were missing for some taxa (Table 1 ) resulting in $23.3 \%$ of the combined matrix being coded as missing.

\subsection{Phylogeny}

MP analysis of the combined data inferred 808 equally most parsimonious trees, each with a length of 766 steps, consistency in$\operatorname{dex}(\mathrm{CI})=0.6521$ and retention index $(\mathrm{RI})=0.8424$. The most likely $\mathrm{BI}$ trees had a $-\log$ score of 17037.93 . The BI analysis produced trees with topologies similar to the MP analysis. Fig. 1 illustrates a consensus of these two analyses.

The monophyly of each subtribe was highly supported $(100 \%$ BS, $1.00 \mathrm{PP}, 7+\mathrm{DI})$. We recovered several moderately supported lineages within Arthrostylidiinae, of which we highlight four, designating them by their oldest generic name (Fig. 1): (I) the Glaziophyton clade (82\% BS, $1.00 \mathrm{PP}, 3 \mathrm{DI}$ ); (II) the Arthrostylidium clade (66\% BS, 1.00 PP, 2 DI); (III) the Aulonemia clade (86\% BS, 1.00 PP, 5 DI); (IV) the Merostachys clade ( $88 \%$ BS, 1.00 PP, 3 DI). The Aulonemia clade (III) is sister to the Merostachys clade (IV) with overall moderate support (74\% BS, 1.00 PP, 2 DI). The Arthrostylidium clade (II) is moderately supported (99\% BS, $0.97 \mathrm{PP}, 1 \mathrm{DI}$ ) as sister to the Merostachys + Aulonemia clade and the Glaziophyton clade (I) is strongly supported as sister to the Arthrostylidium + (Merostachys + Aulonemia) clade. We chose to name these four clades (as opposed to other possible groupings) based on a combination of phylogenetic divergence and approximate equivalence of diversity (clades II-IV) simply for ease of reference.

Three lineages form a polytomy within the Arthrostylidium clade (II). The type species of Arthrostylidium, Ar. cubense, falls within a relatively well-supported lineage (90\% BS, 1.00 PP, 5 DI) including most sampled species of Arthrostylidium and Rhipidocladum. Within this grouping, Ar. pubescens is sister (72\% BS, $1.00 \mathrm{PP}, 1$ DI) to a lineage representing much of Rhipidocladum section Racemiflorum (100\% BS, 1.00 PP, 6 DI). Rhipidocladum section Rhipidocladum, including the type species $R$. harmonicum and an undescribed species from Ecuador (LC 1464) is strongly supported as monophyletic (100\% BS, $1.00 \mathrm{PP}, 7 \mathrm{DI})$. The second lineage is formed by the two species of Elytrostachys, a strongly supported lineage (99\% BS, $1.00 \mathrm{PP}, 5 \mathrm{DI})$, which appear as sister to the $A r$. merostachyoides $+R$. maxonii clade (100\% BS, $1.00 \mathrm{PP}, 5 \mathrm{DI})$, but without significant support. $R$. maxonii is currently classified within $R$. sect. Racemiflorum. The two species of $R$. sect. Didymogonyx 
Table 2

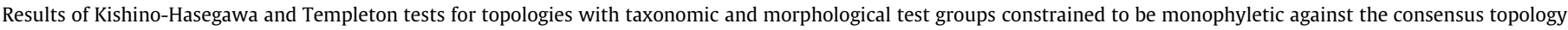
recovered by Bayesian inference and maximum parsimony methods for Arthrostylidiinae using a combined chloroplast DNA data set.

\begin{tabular}{|c|c|c|c|c|c|c|c|c|c|}
\hline \multirow[t]{2}{*}{ Constraint } & \multirow[t]{2}{*}{ Length overall } & \multicolumn{4}{|c|}{ Kishino-Hasegawa test } & \multicolumn{4}{|c|}{ Templeton test } \\
\hline & & Length difference & s.d. & $t$ & $p$-Value & Rank sums & $N$ & $z$ & $p$-Value \\
\hline $\begin{array}{l}\text { Taxonomic } \\
\text { Arthrostylidiinae }\end{array}$ & 766 & 0 & - & - & - & $\begin{array}{r}1.5 \\
-1.5\end{array}$ & 2 & - & - \\
\hline Arthrostylidium & 799 & 33 & 6.228 & 5.299 & $<0.0001$ & $\begin{array}{r}630.0 \\
-36.0\end{array}$ & 36 & -5.284 & $<0.0001$ \\
\hline Aulonemia & 795 & 29 & 6.232 & 4.654 & $<0.0001$ & $\begin{array}{r}680.0 \\
-100.0\end{array}$ & 39 & -4.644 & $<0.0001$ \\
\hline Rhipidocladum & 791 & 25 & 5.557 & 4.499 & $<0.0001$ & $\begin{array}{l}378.0 \\
-28.0\end{array}$ & 28 & -4.490 & $<0.0001$ \\
\hline $\begin{array}{l}\text { Morphological } \\
\text { Apsidate branching }\end{array}$ & 789 & 23 & 4.99 & 4.61 & $<0.0001$ & $\begin{array}{l}312.0 \\
-13.0\end{array}$ & 25 & -4.600 & $<0.0001$ \\
\hline Erect culm leaves & 792 & 26 & 5.465 & 4.758 & $<0.0001$ & $\begin{array}{r}434.0 \\
-31.0\end{array}$ & 30 & -4.747 & $<0.0001$ \\
\hline Nucoid caryopsis & 766 & 0 & - & - & - & 0 & - & - & - \\
\hline Geniculate synflorescence form & 781 & 15 & 4.118 & 3.643 & 0.0003 & $\begin{array}{r}144.0 \\
-9.0\end{array}$ & 17 & -3.638 & 0.0003 \\
\hline Internodes with variable lengths & 801 & 35 & 6.69 & 5.232 & $<0.0001$ & $\begin{array}{r}819.0 \\
-84.0\end{array}$ & 42 & -5.218 & $<0.0001$ \\
\hline Pseudospikelets & 782 & 16 & 4.685 & 3.415 & 0.0006 & $\begin{array}{r}218.5 \\
-34.5\end{array}$ & 22 & -3.411 & 0.0006 \\
\hline
\end{tabular}

comprise the third strongly supported lineage (100\% BS, $1.00 \mathrm{PP}, 12$ DI). Two undescribed species from the high Andes of Ecuador and Colombia presumed to belong to Arthrostylidium (Ar. sp. LC 1101 and $A r$. sp. XL 900) form a robust monophyletic group (100\% BS, $1.00 \mathrm{PP}, 11 \mathrm{DI})$, sister to the remainder of the Aulonemia clade (III) with $86 \% \mathrm{BS}, 1.00 \mathrm{PP}, 5 \mathrm{DI}$.

Four of the six sampled Aulonemia species, including the type species (Au. queko), form a moderately-well supported clade $(86 \%$ BS, 1.00 PP, 4 DI) within the Aulonemia clade (III). The Brazilian Au. amplissima also falls within the Aulonemia clade (III), but as sister (97\% BS, $1.00 \mathrm{PP}, 4 \mathrm{DI})$ to the weakly monophyletic Colanthelia McClure \& E.W. Sm. (70\% BS, 0.91 PP, 1 DI). The lineage consisting of Colanthelia plus Au. amplissima is strongly supported (100\% BS, $1.00 \mathrm{PP}, 14 \mathrm{DI}$ ) as sister to the formerly mentioned clade of four species of Aulonemia. One species of Aulonemia, Au. ulei, is resolved within the Glaziophyton clade (I) with $82 \%$ BS, $1.00 \mathrm{PP}$, and 3 DI.

The Merostachys clade (IV) consists of three robustly supported lineages, two of which associate in a rather poorly supported clade. The two species of Filgueirasia are unequivocally supported as a monophyletic group (100\% BS, $1.00 \mathrm{PP}, 14 \mathrm{DI})$. Likewise, Alvimia (99\% BS, 1.00 PP, 5 DI) and Atractantha (100\% BS, $1.00 \mathrm{PP}, 5 \mathrm{DI}$ ) are each well supported as is their sister relationship (100\% BS, 1.00 PP, 6 DI); together they form a clade with Filgueirasia but with support only from the BI analysis (0.97 PP). The third lineage (98\% BS, $1.00 \mathrm{PP}, 4 \mathrm{DI}$ ) comprises the monotypic Actinocladum sister to a strongly monophyletic Merostachys (100\% BS, 1.00 PP, 16 DI).

We resolved six genera as monophyletic: Merostachys, Alvimia, Atractantha, Filgueirasia, Colanthelia, and Elytrostachys. Both Actinocladum and Glaziophyton are monotypic, but both were recovered external to the other genera. The polyphyly of Arthrostylidium, Aulonemia, and Rhipidocladum is corroborated by the $\mathrm{KH}$ and Templeton tests which indicate a significant difference ( $p$-value $<0.0001$ ) between the recovered topology (Fig. 1) and topologies where each genus is constrained to be monophyletic (Table 2).

\subsection{Morphology}

Morphological characters (Table 3 ) mapped onto our phylogenetic hypothesis by parsimony and likelihood methods show very similar results. The delayed parsimony optimization summarized in Fig. 2 highlights several characters with homoplasious tendencies, but also demonstrates consistency in a few characters. Culm leaf blade orientation, branching architecture, synflorescence form, and spikelet structure have equivocal regions in the reconstruction, but examination of both accelerated and delayed optimizations suggests multiple origins or reversals for each, as well as for internode length dimorphism as a whole.

Culm leaf orientation is mostly consistent within genera or lineages. Erect, non-pseudopetiolate culm leaves are found in the Glaziophyton clade (I) and throughout the Arthrostylidium clade (II) except for Elytrostachys. The Aulonemia clade (III) evolved reflexed, pseudopetiolate culm leaf blades with no reversals. Within the Merostachys clade (IV), reflexed culm leaf blades also evolved in Actinocladum + Merostachys and in two species of Atractantha, but the trichotomy in Atractantha makes the number of origins or reversals ambiguous. Erect culm leaf blades are also consistently present in the Guaduinae, except in Er. aureofimbriatum.

Two of the three genera with fan-branching, Merostachys and Actinocladum, form a well-supported clade. Within the Arthrostylidium clade (II), fan-branching is optimized as having one origin with three reversals (in Elytrostachys, the Ar. cubense-Ar. venezuelae clade and Ar. pubescens). As coded, the branching configuration with 2-5 dominant branches arising from each mid-culm node putatively originated twice within the subtribe, once within Atractantha and once within Filgueirasia. A branch complement of 5-7 subequal branches arose once in Aulonemia ulei. The remaining lineages exhibit one dominant branch with or without lateral secondary branches.

The promontory has at least seven independent origins, one within the Guaduinae and six within the Arthrostylidiinae. Lack of resolution, especially within the Arthrostylidium clade (II), obviously makes it possible to hypothesize fewer origins and more reversals. 
Table 3

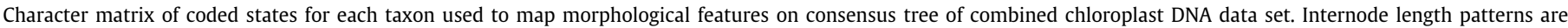

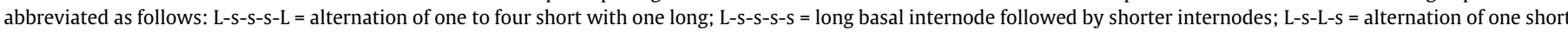
with one long.

\begin{tabular}{|c|c|c|c|c|c|c|c|c|c|}
\hline Taxon & Spikelets & Caryopsis & $\begin{array}{l}\text { Culm leaf } \\
\text { blade }\end{array}$ & $\begin{array}{l}\text { Prophyll } \\
\text { shape }\end{array}$ & $\begin{array}{l}\text { Synflorescence } \\
\text { form }\end{array}$ & $\begin{array}{l}\text { Internode } \\
\text { pattern }\end{array}$ & $\begin{array}{l}\text { Dominant } \\
\text { branches }\end{array}$ & $\begin{array}{l}\text { Branch leaf } \\
\text { tessellate }\end{array}$ & Promontory \\
\hline $\begin{array}{l}\text { Actinocladum } \\
\text { verticillatum }\end{array}$ & Conventional & Nucoid & Reflexed & Triangular & Raceme & All equal & Fan & Absent & Absent \\
\hline Alvimia auriculata & Pseudo- & Bacoid & Erect & Triangular & Panicle & All equal & 1 & Absent & Present \\
\hline Alvimia gracilis & Pseudo- & Bacoid & Erect & Triangular & Panicle & All equal & 1 & Absent & Present \\
\hline Apoclada simplex & Conventional & Typical & Erect & Triangular & Panicle & All equal & $2-5$ & Absent & Absent \\
\hline $\begin{array}{l}\text { Arthrostylidium sp. LC } \\
\quad 1101\end{array}$ & Conventional & Typical & Reflexed & Triangular & Geniculate & All equal & 1 & Absent & Present \\
\hline $\begin{array}{l}\text { Arthrostylidium sp. XL } \\
\quad 900\end{array}$ & Conventional & Typical & Reflexed & Triangular & Raceme & All equal & 1 & Absent & Present \\
\hline Arthrostylidium cubense & Conventional & Typical & Erect & Triangular & Raceme & All equal & 1 & Absent & Present \\
\hline $\begin{array}{l}\text { Arthrostylidium } \\
\quad \text { merostachyoides }\end{array}$ & Conventional & Typical & Erect & Triangular & Raceme & All equal & Fan & Absent & Present \\
\hline $\begin{array}{l}\text { Arthrostylidium } \\
\text { multispicatum }\end{array}$ & Conventional & Typical & Erect & Triangular & Geniculate & All equal & 1 & Absent & Present \\
\hline $\begin{array}{l}\text { Arthrostylidium } \\
\text { pubescens }\end{array}$ & Conventional & Typical & Erect & Triangular & Raceme & All equal & 1 & Absent & Present \\
\hline Arthrostylidium urbanii & Conventional & Typical & Erect & Triangular & Raceme & All equal & 1 & Absent & Present \\
\hline $\begin{array}{l}\text { Arthrostylidium } \\
\text { venezuelae }\end{array}$ & Conventional & Typical & Erect & Triangular & Geniculate & All equal & 1 & Absent & Present \\
\hline Atractantha aureolanata & Pseudo- & Typical & Reflexed & Triangular & Panicle & All equal & $2-5$ & Absent & Present \\
\hline Atractantha cardinalis & Pseudo- & Typical & Reflexed & Triangular & Panicle & All equal & $2-5$ & Absent & Present \\
\hline Atractantha radiata & Pseudo- & Typical & Erect & Triangular & Head & All equal & $2-5$ & Absent & Present \\
\hline Aulonemia amplissima & Conventional & Typical & Reflexed & Triangular & Panicle & All equal & 1 & Absent & Present \\
\hline Aulonemia hirtula & Conventional & Typical & Reflexed & Triangular & Panicle & L-S-S-S-L & 1 & Absent & Present \\
\hline Aulonemia patriae & Conventional & Typical & Reflexed & Triangular & Panicle & All equal & 1 & Absent & Present \\
\hline Aulonemia patula & Conventional & Typical & Reflexed & Triangular & Panicle & All equal & 1 & Absent & Present \\
\hline Aulonemia queko & Conventional & Typical & Reflexed & Triangular & Panicle & L-S-S-S-L & 1 & Absent & Present \\
\hline Aulonemia ulei & Conventional & Typical & Erect & Triangular & Raceme & All equal & $5-7$ & Present & Present \\
\hline Bambusa vulgaris & Pseudo- & Typical & Erect & Triangular & Panicle & All equal & 1 & Absent & Absent \\
\hline Colanthelia cingulata & Conventional & Typical & Reflexed & Triangular & Panicle & All equal & 1 & Absent & Present \\
\hline Colanthelia distans & Conventional & Typical & Reflexed & Triangular & Raceme & All equal & 1 & Absent & Present \\
\hline Colanthelia intermedia & Conventional & Typical & Reflexed & Triangular & Panicle & All equal & 1 & Absent & Present \\
\hline Elytrostachys clavigera & Pseudo- & Typical & Reflexed & Triangular & Raceme & All equal & 1 & Absent & Present \\
\hline Elytrostachys typica & Pseudo- & Typical & Reflexed & Triangular & Raceme & All equal & 1 & Absent & Present \\
\hline $\begin{array}{l}\text { Eremocaulon } \\
\quad \text { aureofimbriatum }\end{array}$ & Pseudo- & Typical & Reflexed & Triangular & Panicle & All equal & 1 & Absent & Absent \\
\hline Filgueirasia arenicola & Conventional & Typical & Erect & Triangular & Raceme & All equal & $2-5$ & Absent & Absent \\
\hline Filgueirasia cannavieira & Conventional & Typical & Erect & Triangular & Raceme & All equal & $2-5$ & Absent & Absent \\
\hline Glaziophyton mirabile & Conventional & Typical & Erect & Triangular & Panicle & L-S-S-S-S & 1 & Present & Absent \\
\hline Guadua angustifolia & Pseudo- & Typical & Erect & Triangular & Panicle & All equal & 1 & Absent & Absent \\
\hline Merostachys sp. AC 4366 & Conventional & Nucoid & Reflexed & Triangular & Raceme & All equal & Fan & Absent & Absent \\
\hline Merostachys sp. AC 4378 & Conventional & Nucoid & Reflexed & Triangular & Raceme & All equal & Fan & Absent & Absent \\
\hline Merostachys ternata & Conventional & Nucoid & Reflexed & Triangular & Raceme & All equal & Fan & Absent & Absent \\
\hline Olmeca recta & Conventional & Bacoid & Erect & Triangular & Panicle & All equal & 1 & Absent & Present \\
\hline Otatea acuminata & Conventional & Typical & Erect & Triangular & Panicle & All equal & $2-5$ & Absent & Present \\
\hline Rhipidocladum sp. TF s.n. & Conventional & Typical & Erect & Triangular & Raceme & All equal & Fan & Absent & Absent \\
\hline $\begin{array}{l}\text { Rhipidocladum aff. } \\
\text { longispiculatum }\end{array}$ & Conventional & Typical & Erect & Cordate & Panicle & L-S-L-S & Fan & Absent & Absent \\
\hline Rhipidocladum bartlettii & Conventional & Typical & Erect & Triangular & Raceme & All equal & Fan & Absent & Absent \\
\hline Rhipidocladum clarkiae & Conventional & Typical & Erect & Triangular & Raceme & All equal & Fan & Absent & Absent \\
\hline $\begin{array}{l}\text { Rhipidocladum sp. LC } \\
\quad 1464\end{array}$ & Conventional & Typical & Erect & Triangular & Geniculate & All equal & Fan & Absent & Absent \\
\hline $\begin{array}{l}\text { Rhipidocladum } \\
\text { geminatum }\end{array}$ & Conventional & Typical & Erect & Cordate & Panicle & L-S-L-S & Fan & Absent & Absent \\
\hline $\begin{array}{l}\text { Rhipidocladum } \\
\text { harmonicum }\end{array}$ & Conventional & Typical & Erect & Triangular & Geniculate & All equal & Fan & Absent & Absent \\
\hline Rhipidocladum maxonii & Conventional & Typical & Erect & Triangular & Raceme & All equal & Fan & Absent & Absent \\
\hline Rhipidocladum neumannii & Conventional & Typical & Erect & Triangular & Raceme & All equal & Fan & Absent & Absent \\
\hline $\begin{array}{l}\text { Rhipidocladum } \\
\text { pacuarense }\end{array}$ & Conventional & Typical & Erect & Triangular & Raceme & All equal & Fan & Absent & Absent \\
\hline $\begin{array}{l}\text { Rhipidocladum } \\
\text { parviflorum }\end{array}$ & Conventional & Typical & Erect & Triangular & Raceme & All equal & Fan & Absent & Absent \\
\hline Rhipidocladum pittieri & Conventional & Typical & Erect & Triangular & Raceme & All equal & Fan & Absent & Absent \\
\hline $\begin{array}{l}\text { Rhipidocladum } \\
\text { racemiflorum }\end{array}$ & Conventional & Typical & Erect & Triangular & Raceme & All equal & Fan & Absent & Absent \\
\hline Rhipidocladum sibilans & Conventional & Typical & Erect & Triangular & Raceme & All equal & Fan & Absent & Absent \\
\hline
\end{tabular}

With respect to synflorescence form evolution, most of the sampled species bear spikelets bilaterally along straight axes in racemose synflorescences. Paniculate synflorescences map to the
Aulonemia + Colanthelia clade, with a reversal to racemose synflorescences in $C$. distans, but also occur in Glaziophyton, Alvimia + Atractantha and in R. sect. Didymogonyx. 


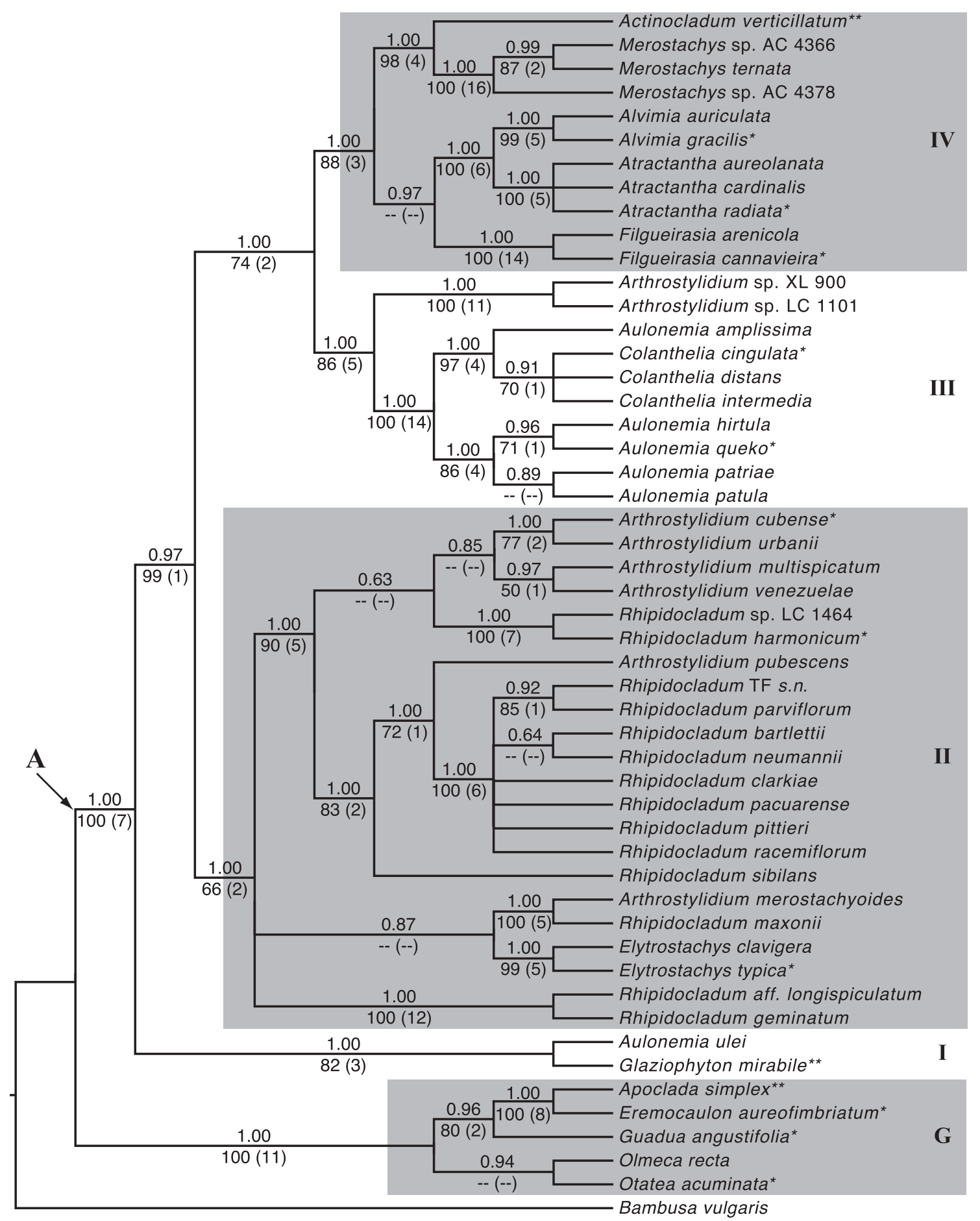

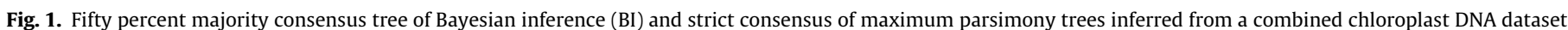

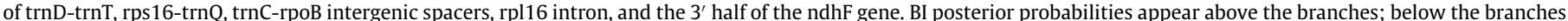

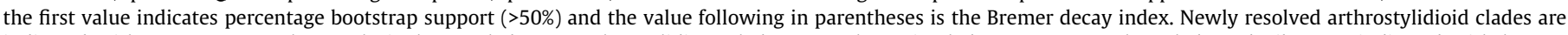

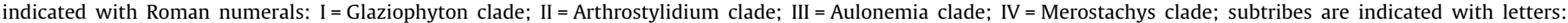
$\mathrm{A}=$ Arthrostylidiinae; $\mathrm{G}=$ Guaduinae; $*$ =type species; $* *=$ monotypic genus.

The geniculate synflorescence form is found in $R$. sect. Rhipidocladum, four described species of Arthrostylidium (two represented on our tree - Ar. venezuelae and Ar. multispicatum), and two undescribed species of Arthrostylidium (LC 1101 and XL 900). R. sect. Rhipidocladum, Ar. venezuelae and Ar. multispicatum are members of the Arthrostylidium clade (II). Our findings show these taxa forming a clade, along with Ar. cubense and Ar. urbanii, but with no statistical support. The presence of geniculate synflorescences in the undescribed Andean Arthrostylidium species in the Aulonemia clade (III) shows unquestionably that the geniculate synflorescence form had more than one origin or reversal.

Pseudospikelets evolved twice within the Arthrostylidiinae, once in Elytrostachys and again in Alvimia + Atractantha. In the Guaduinae, pseudospikelets are known from Guadua and Eremocaulon. 


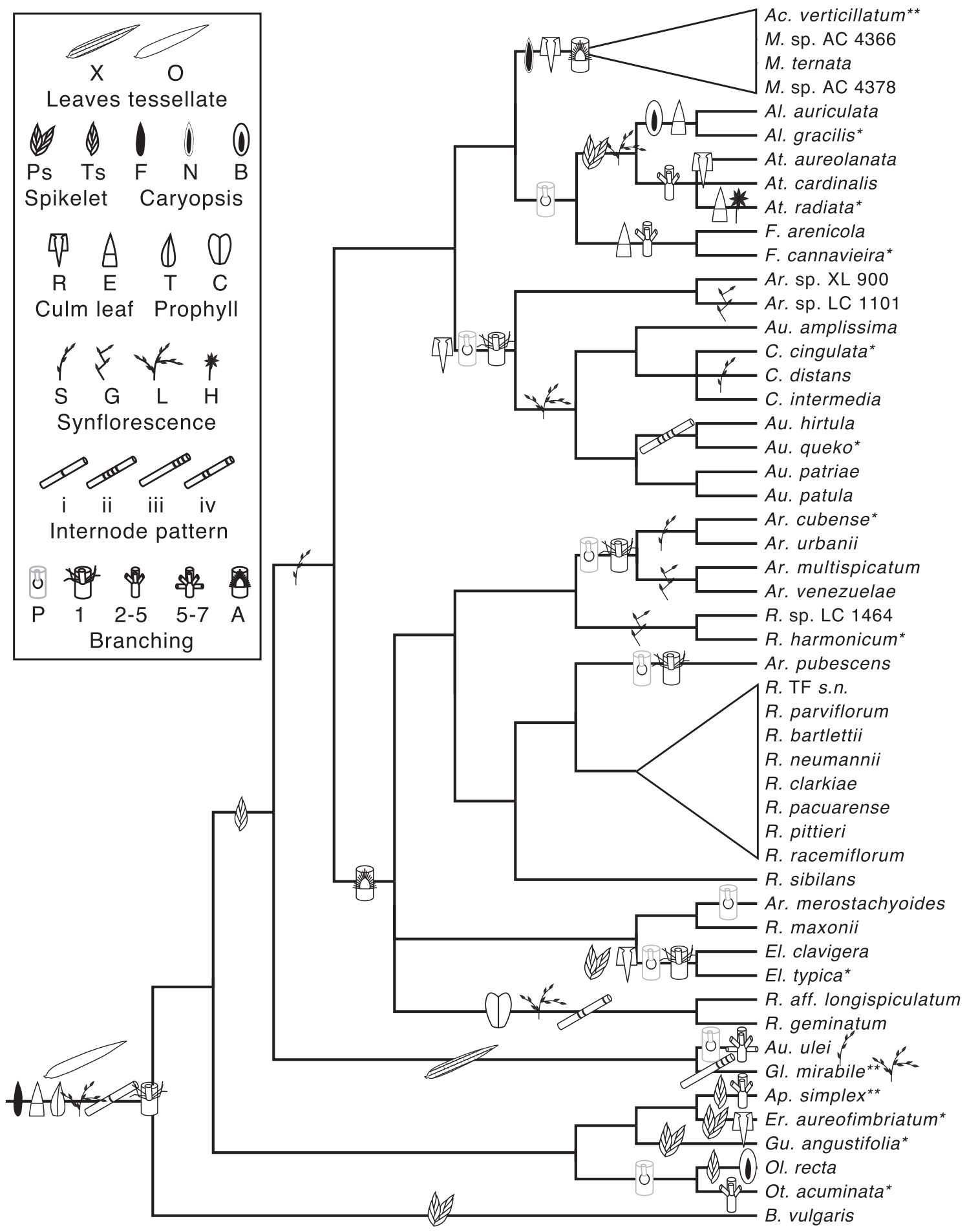

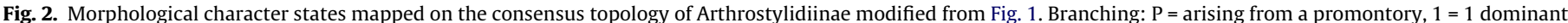

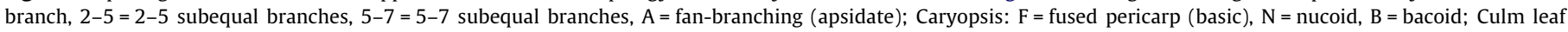

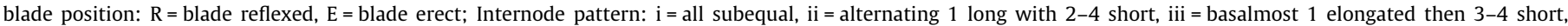

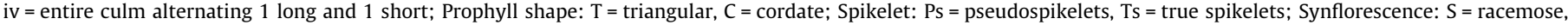
straight axis, $\mathrm{G}=$ racemose, geniculate (zig-zag) axis, $\mathrm{L}=$ panicle, $\mathrm{H}=$ head; Branch leaves tessellate: $\mathrm{O}=\mathrm{absent}$, $\mathrm{X}=$ present. $*=$ type species; $* *=$ monotypic genus.

Both the parsimony and likelihood model optimizations are ambiguous as to the ancestral state for this character, therefore we cannot determine the number of origins or reversals in the Guaduinae.

Internodes of two different lengths (internode dimorphism) appear multiple times in our results, but each pattern of length differences may be independently derived. Glaziophyton, with its long basal internode followed by several very short ones, is monotypic. The Aulonemia species allied to Glaziophyton in our phylogeny has subequal internodes. The two Aulonemia species we sampled that consistently alternate $1-4$ short internodes with one long were resolved in a sister relationship within the Aulonemia clade (III), indicating a single origin of that pattern. And the other internode length pattern, regular alternation of one short and one long internode, was recovered as potentially synapomorphic for $R$. sect. Didymogonyx.

Of the characters we examined, the three most consistent with the phylogeny are prophyll shape, fruit type, and tessellate leaf 
blades. Within the Arthrostylidiinae, nucoid caryopses are potentially synapomorphic for Merostachys plus Actinocladum, and bacoid caryopses are potentially synapomorphic for Alvimia. Cordate prophylls, here, are a putative synapomorphy for $R$. sect. Didymogonyx, and the Glaziophyton clade (I) is supported by the potential synapomorphy of tessellate leaf blades.

\section{Discussion}

\subsection{Lineages and taxonomy}

The novel topology recovered in this study provides the first multi-locus chloroplast phylogeny of Arthrostylidiinae. Previously, only cursory relationships between the genera could be suggested based on morphology (Judziewicz et al., 1999; McClure, 1973) and the complicated morphology made it difficult to even speculate about higher level relationships. Each of the four clades revealed in our work represents a phylogenetically divergent chloroplast DNA lineage. Lack of data from nuclear DNA and low numbers of informative characters supporting some the branches, however, warrant a conservative interpretation of these groups.

\subsubsection{Guaduinae}

In agreement with other studies (Clark et al., 2007; Ruiz-Sanchez et al., 2011; Sungkaew et al., 2009; Zhang and Clark, 2000), we also recover a monophyletic Guaduinae. Even with the small number of representative guaduoid species in this study, the potential for good support of internal structure using these six DNA regions is evident. We expect that individual taxa will continue to be sifted between Arthrostylidiinae and Guaduinae, but these would represent misclassifications remedied by examination of leaf anatomy and micromorphology or sequencing.

\subsubsection{Arthrostylidiinae}

By including 11 of 13 genera and a substantial range of morphologies, we confidently demonstrate a monophyletic Arthrostylidiinae based on chloroplast DNA sequence data. Another important finding is the resolution, with reasonable support, of the Glaziophyton clade (I) as sister to the remainder of the subtribe. Tessellate leaf blades provide a potential synapomorphy for this clade, although this feature is known from other groups of bamboos characteristic of high altitudes (e.g., Chusquea sect. Swallenochloa; Clark, 1989) or high latitudes (many Arundinarieae; McClure, 1966). It is perhaps noteworthy that both members of the Glaziophyton clade (I) are from southeastern Brazil; once better internal resolution is achieved within the other three lineages and the remaining two genera sampled, a comprehensive biogeographic analysis should be undertaken.

The presence of reflexed branch leaf blades (pseudopetioles) is an apparent synapomorphy for the clade comprising the rest of the subtribe (II-IV); this is an unusual feature among woody bamboos and gives the members of this large group a characteristic appearance in the field. The erect leaf blades characteristic of the Glaziophyton clade (I) and Filgueirasia may be correlated with the open habitats these taxa occupy, but this remains to be investigated. None of the three other major arthrostylidioid clades (II, III or IV) we identified have well defined synapomorphies and most lack any recognized, shared morphological features. It is possible that a detailed study of leaf anatomy and micromorphology within Arthrostylidiinae will provide diagnostic characters for these clades or genera. Stomatal position has already proven useful in Colanthelia (Santos-Gonçalves, 2005).

Although this is the most comprehensive phylogenetic analysis of the Arthrostylidiinae to date, lack of internal resolution or support in parts of the tree hampers our understanding of its morphological evolution and biogeography. Whole plastome sequence data may help resolve some of these relationships, but plastid DNA alone is unlikely to provide a complete picture due to phenomena such as lineage sorting, chloroplast capture and hybridization (BPG, 2012 and references cited therein). Long generation times in woody bamboos may be responsible for their slower rates of molecular evolution relative to other grasses, which is evident in plastid sequence data (Gaut et al., 1997; Janzen, 1976). This is yet another reason why additional plastid sequence data may not be very informative, even though arthrostylidioid bamboos have shorter flowering cycles, on the order of 15-40 years (Pohl, 1980), than many woody bamboos. Phylogenetic reconstruction for this group (and other woody bamboos) should also be carried out using nuclear markers, recognizing that this is non-trivial given nearly universal polyploidy in woody bamboos (Judziewicz et al., 1999).

\subsubsection{Actinocladum + Merostachys}

Actinocladum verticillatum was originally described in Rhipidocladum based on its fan-branching, but it differed from its congeners in spikelet and synflorescence morphology (Soderstrom, 1981) as well as caryopsis type. The flowering structure is paniculate to racemose. Actinocladum also bears reflexed culm leaves, a trait shared with many Arthrostylidiinae genera including Aulonemia and Merostachys. The sequence data unambiguously support a sister relationship between Actinocladum and Merostachys, with the presence of fan-branching and the nucoid caryopsis providing diagnostic morphological characters for the clade.

Merostachys is the second largest genus in the subtribe and is ecologically important in South America, but remains poorly known (Judziewicz et al., 1999). It was thought to be closely related to Rhipidocladum (Judziewicz et al., 1999; McClure, 1973), sharing fan-branching, but differing in culm leaf orientation, spikelet features, and caryopsis type. We have shown Merostachys to belong to a clade distinct from that containing the type of Rhipidocladum, indicating no close relationship. Our current state of knowledge suggests that both Actinocladum and Merostachys should continue to be recognized as distinct genera until more detailed morphological and molecular analyses of both can be completed.

\subsubsection{Alvimia + Atractantha and Filgueirasia}

The known distribution of Alvimia is completely within the range of Atractantha in the Atlantic forests of Bahia, Brazil (Judziewicz, 1992). These genera were suspected to be related based on similarities in leaf anatomy, the presence of pseudospikelets, and their scrambling habit (Soderstrom and Londoño, 1988). The pseudospikelets of Alvimia are long and bear many florets, whereas those of Atractantha are short and include only one spindle-shaped fertile floret in the spikelet proper. Even though the pseudospikelets of Atractantha radiata are usually arrayed in dense heads, teratological specimens proliferate into long, spicate branches not unlike the pseudospikelets of Alvimia. Despite some similarities and their sister relationship, morphological differences clearly support the continued recognition of both Alvimia and Atractantha as genera.

The branching morphology of Filgueirasia is clearly non-homologous to that of Atractantha, as the usually 2-5 branches per node of the former genus are derived from multiple buds (Guala, 1995) and all other members of Arthrostylidiinae have a single bud per node (Judziewicz et al., 1999). The erect leaves, presence of white fimbriae on the foliage leaf sheaths, and cerrado habitat of Filgueirasia also support its generic status (Guala, 2003), although its relationship to the rest of the Merostachys clade (IV) remains unclear.

\subsubsection{The Aulonemia clade}

Branching architecture and occasional paniculate synflorescences in species of Colanthelia suggest an affinity with Aulonemia 
(McClure, 1973). Recent revisions of both Colanthelia (SantosGonçalves, 2005) and Aulonemia (Judziewicz et al., in preparation; Viana et al., in review) as part of the Bamboo Phylogeny Project (BPG, 2006b) are nearing completion. These works will address our intermingled results of Aulonemia with Colanthelia and the Glaziophyton clade (I) from a morphological perspective. A separate manuscript (Judziewicz et al., in preparation) will evaluate the systematics of the Andean group of Arthrostylidium (Ar. sp. LC 1101 and Ar. sp. XL 900) in relation to Colanthelia and Aulonemia.

\subsubsection{Arthrostylidium + Rhipidocladum}

Arthrostylidium has long been a taxonomic catch-all for aberrant neotropical woody bamboos and its polyphyly in our results reflects that. Though progress has been made toward delineating the true entity deemed Arthrostylidium, it is clear that this imbroglio cannot be sorted out without greater taxon sampling, in-depth morphological analysis, and sequencing of nuclear markers. A number of the species currently classified as Arthrostylidium are morphological anomalies which may prove to be new genera or may not even belong in the subtribe.

The fate of Rhipidocladum is intimately tied to Arthrostylidium, and hinges on the blurred distinction between promontory development and fan-branching. $R$. sect. Rhipidocladum has strong molecular support and is morphologically distinct from $R$. sect. Racemiflorum, but beyond branch complement morphology, there are few characters that distinguish either section from Arthrostylidium. Furthermore, there is uncertainty surrounding the monophyly of $R$. sect. Racemiflorum as one species of Arthrostylidium is embedded in this section. Davidse and Pohl (1992) admit the generic placement of Ar. merostachyoides was difficult as it shares characters with Merostachys, Rhipidocladum, and Arthrostylidium. They eventually placed the taxon in Arthrostylidium on the basis of the branch complement morphology, which we have now shown to be unconserved among lineages. The Ar. merostachyo$i d e s+R$. maxonii lineage is strongly supported as monophyletic, but does not exhibit a combination of features that might support its removal from a concept of Arthrostylidium that includes Rhipidocladum. This problem will be treated in more detail in a separate manuscript (Tyrrell and Clark, in preparation).

The species of $R$. sect. Didymogonyx are robustly supported as a monophyletic group and they do share a suite of characters unique within the subtribe. This section is easily distinguished from the other sections of Rhipidocladum and all currently recognized genera in the subtribe by the combination of cordate prophylls, alternating long and short internodes along the culm, the presence of culm leaf fimbriae, spikelets in pairs or triads in a contracted synflorescence, and the unbranching long-cell extensions overarching the stomates (Clark and Londoño, 1991). We here elevate $R$. sect. Didymogonyx to generic status:

Didymogonyx (L.G. Clark \& Londoño) C.D. Tyrrell, L.G. Clark \& Londoño gen. et. stat. nov. Rhipidocladum section Didymogonyx L.G. Clark \& Londoño, American Journal of Botany 78(9): 1271. 1991. TYPE: Didymogonyx geminatum (McClure) C.D. Tyrrell, L.G. Clark \& Londoño.

1. Didymogonyx geminatum (McClure) C.D. Tyrrell, L.G. Clark, \& Londoño comb. nov. Arthrostylidium geminatum McClure, Journal of the Washington Academy of Sciences 32(6): 169. 1942. Rhipidocladum geminatum (McClure) McClure, Smithsonian Contributions to Botany 9: 105. 1973. TYPE: VENEZUELA. Trujillo: Páramo de La Cristalina, on the border of the State of Trujillo, 20 October 1910, A. Jahn 11 (holotype: VEN; isotype: US).

2. Didymogonyx longispiculatum (Londoño \& L.G. Clark) C.D. Tyrrell, L.G. Clark \& Londoño comb. nov. Rhipidocladum longispiculatum Londoño \& L.G. Clark, American Journal of Botany 78(9): 1272. 1991. TYPE: COLOMBIA. Cundinamarca: Mun. Cabrera: vereda
Nuñez, Hda. Pto. Nuñez, west slope of páramo of Sumapaz, $3^{\circ} 54^{\prime} \mathrm{N} 74^{\circ} 31^{\prime} \mathrm{W}, 2490-2500 \mathrm{~m}, 14$ March 1989, X. Londoño 429 (holotype: COL; isotypes: ISC, K, MO, TULV, US).

\subsubsection{Elytrostachys}

Elytrostachys is a seldom collected genus previously thought to be related to Alvimia and Atractantha based on the shared diffuse or capitate synflorescence form, reflexed culm leaves and pseudospikelets (Judziewicz et al., 1999). Our molecular results show Elytrostachys to be distinctly separate from the latter two genera and allied with the Arthrostylidium-Rhipidocladum complex. Neither Arthrostylidium nor Rhipidocladum have any of the above mentioned characters, nor do they exhibit the slender, straight fimbriae $2-8 \mathrm{~cm}$ long on the culm and foliage leaf sheaths unique to Elytrostachys (Judziewicz et al., 1999) The only obvious common feature among these genera is the development of a weak promontory in Elytrostachys, but otherwise its morphology clearly supports its recognition as at the generic level.

\subsubsection{Other genera}

Our phylogenetic hypothesis is still missing representatives of two genera: Myriocladus and Athroostachys. Given the level of homoplasy shown among the morphological characters, it is difficult to predict where these taxa are likely to be placed based on gross anatomy or morphology. McClure (1973) noted similarities between Myriocladus and Glaziophyton in the elongated first internode and spikelet morphology. We predict that sequence data will place Myriocladus (at least in part) in the Glaziophyton clade (I) based on these similarities and the shared presence of erect, usually tessellate leaf blades. Athroostachys is possibly related to Merostachys, based on superficial similarities in the fimbriae and reproductive apparatus (McClure, 1973); it should be noted that McClure did not consider these similarities enough to suggest a close phylogenetic relationship. It is perhaps more likely that Athroostachys will resolve within the Alvimia + Atractantha clade based on its typically three branches per node and bracteate synflorescences.

\subsection{Morphology}

We hypothesize that subequal internodes, triangular prophylls, branch complements with one dominant branch, culm leaves with erect blades, non-tessellate leaf blades, paniculate synflorescences and basic caryopses are plesiomorphic for the taxa sampled in this analysis. Polarity of character states for development of the promontory and spikelet structure cannot be unambiguously inferred from the current analysis, although conventional spikelets are inferred to be plesiomorphic for the Arthrostylidiinae. The presence of reflexed branch leaf blades diagnoses a major clade within the Arthrostylidiinae. Although the nucoid and bacoid caryopsis types are unambiguous synapomorphies in this analysis for the Actinocladum + Merostachys clade and Alvimia, respectively, these fruit types are not unique among woody bamboos, as examples of both are found in several other genera in the Old and New World bamboo floras (Judziewicz et al., 1999; Ruiz-Sanchez et al., 2011; Yang et al., 2008). However, the homologies of these fruit types across bamboos have not been adequately investigated.

Cordate prophylls are known from $R$. sect. Didymogonyx and Myriocladus. Without knowing the position of Myriocladus, however, little more can be inferred regarding prophyll evolution.

Most branching types can either possess a promontory or not. Based upon our phylogeny, fan-branching, however, appears to be mostly mutually exclusive with promontory morphology, with the exception of Ar. merostachyoides, at least based on adult morphology. McClure (1973) argued that the apsidate branch complement readily distinguished Rhipidocladum from the raised promontory that typifies Arthrostylidium. Increased collections, 
however, have provided numerous specimens with intermediate branch complements representing a continuum from a well-developed promontory to fan-branching. This is recapitulated ontogenetically, as the branching on young shoots of Rhipidocladum resemble a promontory while the mature culms of the same individual will have a distinctly apsidate form. On the other hand, a promontory is present in genera such as Atractantha, Aulonemia and Colanthelia, which lack fan-branching, and no obvious promontory is associated with the fan-branching characteristic of Actinocladum and Merostachys. In keeping with a conservative approach, we therefore treat the promontory as a separate character in the present analysis and make no inferences about a possible developmental connection between fan-branching and the presence of a promontory in the Arthrostylidium clade (II).

Capitate synflorescences cannot be evaluated as we are missing one (Athroostachys) of the two taxa in which this arrangement occurs. Occasional flowering specimens of Elytrostachys have been known to display synflorescences that appear capitate, but this is not consistent. The paired spikelets found in $R$. sect. Didymogonyx and $A r$. merostachyoides could be interpreted as condensed from a paniculate arrangement (Clark and Londoño, 1991; Davidse and Pohl, 1992).

Pseudospikelets originate twice on our tree in the Arthrostylidiinae, but appear to be conserved within the three genera where they occur. The absence of pseudospikelets in At. amazonica is here interpreted as a loss, but this species needs to be included in a molecular analysis. A possible third origin could be in Glaziophyton, given the presence of subtending bracts and prophylls in its synflorescences (McClure, 1973), but the absence of gemmiparous bracts would then have to be interpreted as a loss.

The distribution of morphological variation on our phylogeny for a number of characters indicates that many gross morphologies may be the result of convergent evolution or lineage sorting. Still, features such as culm leaf blade orientation and pseudospikelets are largely conserved among currently delineated genera, but may not be synapomorphic. Both synflorescence form and branch complement architecture work moderately well at separating genera, but our current interpretations of these characters may be too simplified. Within the subtribe, fruit anatomy, prophyll shape, and tessellate branch leaves also appear to be a good characters for separation, but we were only able include two species with cordate prophylls.

\section{Conclusions}

Clearly, we have only begun to elucidate the evolutionary history of the arthrostylidioid bamboos. By generating a phylogeny that is taxonomically focused on the subtribe and its morphological variability, we have a better understanding of the internal relationships among genera and a foundation for future work. The results presented here will guide taxonomic investigations within the subtribe and should serve as molecular evidence for the putative monophyly of Merostachys, Alvimia, Atractantha, Filgueirasia, Colanthelia, and Elytrostachys. Based on our findings, we recommend a critical assessment of morphological and foliar anatomical characters including those used to distinguish Arthrostylidiinae genera. Promontory development and fan-branching deserve special attention, as these will have ramifications for the circumscriptions of Arthrostylidium and Rhipidocladum. We also recommend that nuclear markers be sequenced to improve our understanding of the phylogeny of this complex subtribe of neotropical woody bamboos.

\section{Acknowledgments}

We are indebted to a number of people including Pedro Viana, Tarciso Filgueiras, Francisca Ely, Eduardo Ruiz-Sanchez, Teresa
Mejia-Saules, and Barry Hammel who provided specimens of important taxa or other assistance. We thank the staff of INBio, especially Nelson Zamora and Alvaro Herrera, and the Costa Rica National Museum for access to herbaria, permits, and logistics. Amanda Fisher collaborated with fieldwork and Mayra MontielLonghi opened her home to us. Jimmy Triplett assisted with laboratory wizardry, and Rob Wallace, Jonathan Wendel, John Nason, and Iowa State University's Center for Plant Responses to Environmental Stress (CPRES) graciously let us use their laboratory facilities. Ryan Percifield, Corrinne Grover, and Ryan Rapp provided laboratory support and suggestions. Field work in Ecuador by Clark was conducted under the auspices of the Pontifícia Universidad Católica del Ecuador (Herbario QCA), and was supported by National Science Foundation (NSF) Grant DEB-9218657 (1996) and a National Geographic Society grant (1992). Field work in Costa Rica by Tyrrell (2008) was supported by a grant from the American Bamboo Society to Tyrrell \& Clark and NSF Grant DEB-0515712 to Clark. We are also grateful to the curators of AAU, F, FTG, ISC, K, MO, NY, TENN, US, and UWSP for loan materials. Final preparation of the manuscript was supported by NSF Grant DEB-0515712 to Clark. Two anonymous reviewers provided many helpful comments and suggestions for improvement of the manuscript.

\section{Appendix A. Supplementary material}

Supplementary data associated with this article can be found, in the online version, at http://dx.doi.org/10.1016/j.ympev.2012. 05.033 .

\section{References}

Bouchenak-Khelladi, Y., Savolainen, V., Hodkinson, T.R., 2010. Diversification of the grasses (Poaceae): a phylogenetic approach to reveal macro-evolutionary patterns. In: Seberg, O., Peterson, G., Barfod, A.S., Davis, J.I. (Eds.), Diversity, Phylogeny, and Evolution in the Monocotyledons. Aarhus University Press, Denmark, pp. 451-475.

BPG: Bamboo Phylogeny Group, 2006a. Bamboo Biodiversity. <http:// www.eeob.iastate.edu/research/bamboo/> (accessed 05.12.11).

BPG: Bamboo Phylogeny Group, 2006b. The Bamboo Phylogeny Project. BAMBOO: Mag. Am. Bamboo Soc. 27, 11-14.

BPG: Bamboo Phylogeny Group, 2012. An updated tribal and subtribal classification for the Bambusoideae (Poaceae). In: Gielis, J., Potters, G. (Eds.), Proceedings of the 9th World Bamboo Congress, 10-15 April 2012, Antwerp, Belgium, pp. 327.

Bremer, K., 1994. Branch support and tree stability. Cladistics 10, 295-304.

Chase, M.W., Hills, H., 1991. Silica gel: an ideal material for field preservation of leaf samples for DNA studies. Taxon 40, 215-220.

Clark, L.G., 1989. Systematics of Chusquea section Swallenochloa, section Verticillatae, section Serpentes, and section Longifoliae (Poaceae: Bambusoideae). Syst. Bot. Monogr. 27, 1-127.

Clark, L.G., Londoño, X., 1991. A new species and new sections for Rhipidocladum. Am. J. Bot. 78, 1260-1279.

Clark, L.G., Dransfield, S., Triplett, J.K., Sánchez-Ken, J.G., 2007. Phylogenetic relationships among the one-flowered, determinate genera of Bambuseae (Poaceae: Bambusoideae). Aliso 23, 315-332

Davidse, G., Pohl, R.W., 1992. New taxa and nomenclatural combinations of Mesoamerican grasses (Poaceae). Novon 2, 81-110.

Felsenstein, J., 1985. Confidence limits on phylogenies: an approach using the bootstrap. Evolution 39, 783-791.

Fisher, A., Triplett, J.K., Ho, C.-S., Schiller, A., Oltrogge, K., Schroder, E., Kelchner, S., Clark, L.G., 2009. Paraphyly in the Chusqueinae (Poaceae: Bambusoideae: Bambuseae). Syst. Bot. 34, 673-683.

Gaut, B.S., Clark, L.G., Wendel, J.F., Muse, S.V., 1997. Comparison of the molecular evolutionary process at $r b c L$ and $n d h F$ in the grass family (Poaceae). Mol. Biol. Evol. 14, 769-777.

Giribet, G., Wheeler, W.C., 1999. On gaps. Mol. Phylogenet. Evol. 13, 132-143.

GPWG: Grass Phylogeny Working Group, 2001. Phylogeny and subfamilial classification of the grasses. Ann. Missouri Bot. Gard. 88, 373-457.

Griekspoor, A., Groothuis, T., 2006. 4Peaks. Version 1.7.2. http:// www.mekentosj.com/science/4peaks (accessed 16.05.11).

Guala, G., 1995. A cladistics analysis and revision of the genus Apoclada (Poaceae: Bambusoideae: Bambusodae). Syst. Bot. 20, 207-223.

Guala, G., 2003. A new genus of bamboos from the cerrados of Brazil. Bamboo Sci. Cult. 17, 1-3. 
Guala, G., Bogler, D., Sadle, J., Francisco-Ortega, J., 2000. Molecular evidence for polyphyly in the genus Apoclada (Poaceae: Bambusoideae). Bamboo Sci. Cult. $14,15-20$.

Janzen, D., 1976. Why bamboos wait so long to flower. Annu. Rev. Ecol. Syst. 7, 347-

Jordan, W.C., Courtney, M.W., Neigel, J.E., 1996. Low levels of intraspecific genetic variation at a rapidly evolving chloroplast DNA locus in North American duckweeds (Lemnaceae). Am. J. Bot. 83, 430-439.

Judziewicz, E.J., 1992. A revision of Atractantha (Poaceae: Bambusoideae: Bambuseae). Ann. Missouri Bot. Gard. 79, 160-183.

Judziewicz, E.J., Clark, L.G., Londoño, X., Stern, M., 1999. American Bamboos. Smithsonian Institution Press, Washington, DC

Kelchner, S.A., 2000. The evolution of non-coding chloroplast DNA and its application in plant systematics. Ann. Missouri Bot. Gard. 87, 482-498.

Kelchner, S.A., Clark, L.G., 1997. Molecular evolutions and phylogenetic utility of the chloroplast rpl16 intron in Chusquea and the Bambusoideae (Poaceae). Mol. Phylogenet. Evol. 8, 385-397.

Kelchner, S.A., Wendel, J.F., 1996. Hairpins create minute inversions in non-coding regions of chloroplast DNA. Curr. Genet. 30, 259-262.

Maddison, D.R., Maddison, W.P., 2005. MacClade. Version 4.08 Sinuar Associates, Sunderland, Massachusetts.

Maddison, W.P., Maddison, D.R., 2011. Mesquite: a modular system for evolutionary analysis. Version 2.75. <http://mesquiteproject.org> (accessed 13.04.12).

McClure, F.A., 1966. The Bamboos: A Fresh Perspective. Harvard University Press, Cambridge.

McClure, F.A., 1973. Genera of bamboos native to the New World (Gramineae: Bambusoideae). Smithson. Contrib. Bot. 9, 1-148.

Morrison, D., 2006. Multiple sequence alignment for phylogenetic purposes. Aust. Syst. Bot. 19, 479-539.

Müller, K., 2004. PRAP - computation of Bremer support for large data sets. Mol. Phylogenet. Evol. 31, 780-782.

Nylander, J.A.A., 2004. MrModeltest2 v2.3. <http://www.abc.se/ nylander/> (accessed 16.05.11).

Paterson, A.H., Brubaker, C.L., Wendel, J.F., 1993. A rapid method for extraction of cotton (Gossypium spp.) genomic DNA suitable for RFLP and PCR analysis. Plant Mol. Biol. Rep. 11, 122-127.

Pohl, R.W., 1980. On the flowering of bamboos in Central America. Brenesia 19 (20), 465-475.

Rambaut, A., 2002. Se-Al. Sequence Alignment Editor. Version 2.0a11. University of Oxford, Oxford, UK. <http://tree.bio.ed.ac.uk/software/seal/> (accessed 16.05.11).

Ronquist, F., Huelsenbeck, J.P., 2003. MRBAYES 3: Bayesian phylogenetic inference under mixed models. Bioinformatics 19, 1572-1574.

Ruiz-Sanchez, E., Sosa, V., Mejia-Saules, M.T., 2008. Phylogenetics of Otatea inferred from morphology and chloroplast DNA sequence data, and recircumscription of Guaduinae (Poaceae: Bambusoideae). Syst. Bot. 33, 277-283.

Ruiz-Sanchez, E., Sosa, V., Mejia-Saules, M.T., 2011. Molecular phylogenetics of the Mesoamerican bamboo Olmeca (Poaceae, Bambuseae): implications for taxonomy. Taxon 60, 89-98.

Santos-Gonçalves, A.P., 2005. Taxonomic and morpho-anatomical studies in Colanthelia (Poaceae: Bambusoideae: Bambuseae). PhD Dissertation. Universidade Estadual de Campinas. Instituto de Biologia, Brazil (in Portuguese).

Sendulsky, T., Filgueiras, T.S., Burman, A.G., 1987. Fruits, embryos, and seedlings. In: Soderstrom, T.R., Hilu, K.W., Campbell, C.S., Barkworth, M. (Eds.), Grass Systematics and Evolution. Smithsonian Institution Press, Washington, DC, pp. 31-36.

Simmons, M.P., Pickett, K.M., Miya, M., 2004. How meaningful are Bayesian support values? Mol. Biol. Evol. 21, 188-199.

Soderstrom, T.R., 1981. Observations on a fire-adapted bamboo of the Brazilian cerrado, Actinocladum verticillatum (Poaceae: Bambusoideae). Am. J. Bot. 68, $1200-1211$.
Soderstrom, T.R., Ellis, R.P., 1987. The position of bamboo genera and allies in system of grass classification. In: Soderstrom, T.R., Hilu, K.W., Campbell, C.S. Barkworth, M. (Eds.), Grass Systematics and Evolution. Smithsonian Institution Press, Washington, DC, pp. 225-238.

Soderstrom, T.R., Londoño, X., 1988. A morphological study of Alvimia (Poaceae: Bambuseae), a new Brazilian bamboo genus with fleshy fruits. Am. J. Bot. 75 819-839.

Sorenson, M.D., Franzosa, E.A., 2007. TreeRot, version 3. <http://people.bu.edu/ msoren/TreeRot.html> (accessed 16.05.11).

Sungkaew, S., Stapleton, C.M.A., Salamin, N., Hodkinson, T.R., 2009. Non-monophyly of the woody bamboos (Bambuseae; Poaceae): a multi-gene region phylogenetic analysis of Bambusoideae s.s. J. Plant Res. 122, 95-108.

Swofford, D.L., 2002. PAUP*. Phylogenetic Analysis Using Parsimony (* and Other Methods). Version 4.0b10. Sinauer Associates, Sunderland, Massachusetts.

Triplett, J.K., Clark, L.G., 2010. Phylogeny of the Temperate Bamboos (Poaceae: Bambusoideae: Bambuseae) with an Emphasis on Arundinaria and Allies. Syst. Bot. 35, 102-120.

Wilgenbusch, J.C., Warren, D.L., Swofford, D.L., 2004. AWTY: A system for graphical exploration of MCMC convergence in Bayesian phylogenetic inference. <http:// ceb.csit.fsu.edu/awty> (accessed 02.05.12).

Yang, H.-Q., Yang, J.-B., Peng, Z.-H., Gao, J., Yang, Y.-M., Peng, S., Li, D.-Z., 2008. A molecular phylogenetic and fruit evolutionary analysis of the major groups of the paleotropical woody bamboos (Gramineae: Bambusoideae) based on nuclear ITS, GBSSI gene and plastid trnL-F DNA sequences. Mol. Phyl. Evol. 48 809-824.

Zhang, W.-P. Clark, L.G 2000. Phylogeny and classification of the bamboos (Poaceae: Bambusoideae). In: Jacobs, S.W.L., Everett, J. (Eds.), Grasses: Systematics and Evolution. CSIRO Publishing, Collingwood, Victoria, Australia pp. 35-42.

\section{Glosssary}

Apsidate: having branches arrayed in a vault-like or fan-shaped fashion

Bacoid: having a caryopsis (fruit) in which the seed coat and/or pericarp become enlarged and fleshy, berry-like

Capitate: a synflorescence that is contracted into a head or ball-shaped cluste

Caryopsis: the fruit of the grass family; hard, dry, indehiscent with pericarp fused to seed coat; a grain

Culm: aerial stem of a grass including bamboo

Floret: the basic unit of a grass inflorescence, consisting of a flower enclosed by two bracts (the lemma and the palea)

Nucoid: having a caryopsis (fruit) in which the seed coat is free from the pericarp achene-like

Panicle: an indeterminate, branching synflorescence

Promontory: the swollen, unsegmented base of a bamboo branch complement

Prophyll: bud scale, the adaxial first branch leaf modified for protection of the meristem

Pseudopetiole: a constriction at the base of the leaf blade separating it from the apex of the sheath, similar to a eudicotyledon petiole

Pseudospikelet: a complex spikelet-like structure in which unit inflorescences develop from the lower bracts of the first-order spikelet and then rebranch in turn

Pulvinus (plural, pulvini): the swollen base of a synflorescence branch

Raceme: an indeterminate synflorescence with spikelets borne directly on the main axis

Spikelet: the unit inflorescence of the grass family; consists of one or more florets subtended by usually two empty bracts (glumes)

Synflorescence: the aggregation of spikelets (unit inflorescences) terminal to a culm or branch 